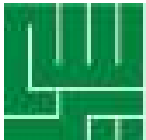

\title{
Potensi Phytomedicine Ekstrak Sphagneticola trilobata (L.) J.F Pruski Sebagai Agen kemoprevetif pada Kasus Kanker Payudara Mencit Terinduksi 7,12 Dimetilbenz(a)Antrasena
}

\section{Potency of Phytomedicine Sphagneticola trilobata (L.) J.F Pruski Extract as Chemopreventive Agent on the Cases of Breast cancer Mice 7,12 Dimetilbenz(a)Antrasena-induced}

\author{
Vivi Mardina, Beni Al Fajar, Fitriari \\ Biology Department, Faculty of Engineering, Samudra University
}

\author{
KATA KUNCI Agen kemopreventif, Sphagneticola trilobata (L.) J.F Pruski, \\ kanker payudara \\ KEYWORDS Chemopreventive agent, Sphagneticola trilobata (L.) J.F \\ Pruski, breast cancer
}

ABSTRAK Kanker payudara merupakan jenis kanker yang umumnya diderita oleh wanita. Obat-obatan kemoterapeutik yang ada, memiliki efek samping dengan merusak sel sehat penderita. Penelitian dan penemuan phytomedicine diharapkan dapat dikembangkan dan digunakan sebagai obat kanker yang efektif dengan efek samping yang minimal. Tanaman Sphagneticola trilobata (L.) J.F Pruski merupakan salah satu tanaman obat yang belum tereksplorasi secara luas khasiatnya. Tujuan penelitian ini adalah mengembangkan potensial sitotoksik dari Sphagneticola trilobata sebagai agen anti kanker untuk menghambat mekanisme molekuler sel kanker payudara secara invivo. Pada penelitian ini mencit dibagi menjadi tiga kelompok yakni (a) kelompok kontrol, (b) kelompok perlakuan mencit yang diinduksi 7,12 Dimetilbenz(a)antrasena (DMBA), dan (c) kelompok perlakuan DMBA+ekstrak S.trilobata. Gambaran mikroskopik payudara mencit yang diinduksi DMBA menunjukkan adanya hiperplasia sel epitel kolumnar duktus laktiferi (>4 lapis); sedangkan payudara mencit yang diberikan ekstrak S.trilobata setelah diinduksi dengan DMBA menunjukkan hiperplasia sel epitel yang lebih ringan (<4 lapis). Pembuktian ilmiah S.trilobata sebagai agen anti kanker diperkuat dengan data penurunan kadar ALT dan kreatinin pada mencit yang diinduksi DMBA. Secara keseluruhan, hasil penelitian ini menyimpulkan bahwa S.trilobata sebagai 
phytomedicine memiliki fungsi anti tumor dan hepatoprotektor.

ABSTRACT Breast cancer is a type of cancer that is commonly suffered by women. Existing chemotherapeutic drugs have side effects by damaging the patient's healthy cells. Research and the discovery of phytomedicine are expected to be developed and used as an effective cancer drug with minimal side effects. Sphagneticola trilobata (L.) J.F Pruski plant is one of the medicinal plants that has not been widely explored. The objective of this study was to develop the cytotoxic potential of Sphagneticola trilobata as an anti-cancer agent to inhibit the molecular mechanism of breast cancer in vivo. In this study mice were divided into three groups, namely (a) the control group, (b) the treatment group of mice induced of 7.12 Dimetilbenz (a) anthracene (DMBA), and (c) the group of DMB-induced + extract S.trilobata. Microscopic description of DMBA-induced breast mice showed the presence of columnar epithelial lactary ductal hyperplasia (> 4 layers); whereas mice breast given S.trilobata extract after induction with DMBA showed lighter (<4 layers) epithelial cell hyperplasia. Scientific evidence of Sphagneticola trilobata as an anti-cancer agent is also strengthened by the data on decreases in ALT and creatinine levels in DMBA-induced mice. Overall, the results of this study concluded that S.trilobata as a phytomedicine has anti-tumor and hepatoprotector functions.

\section{PENDAHULUAN}

Kanker payudara merupakan jenis kanker yang menyerang jaringan payudara, tumbuh di dalam kelenjar susu, saluran susu dan jaringan lemak. Kanker jenis ini mempunyai prevalensi cukup tinggi pada wanita sekitar 1,7 juta kasus dan 522,000 kematian pada tahun 2012 (Arya et al., 2015; Safarzadeh et al., 2014; Shah et al., 2014). Di Indonesia sendiri, penderita kanker payudara sekitar $28,7 \%$, terbanyak pertama yang diikuti kanker leher rahim (12.8\%) (Husain dkk, 2015).

Penyebab utama kanker payudara belum diketahui secara pasti, namun salah satu faktor yang dapat memicu tumbuh kembang sel kanker adalah radikal bebas (Rios-Arrabal et al., 2013; Pouhrahmad et al., 2016). Radikal bebas dapat diinduksi dari beberapa senyawa karsinogenik seperti benzo(a)pyrene, dan dimetilbenz [a]antrasena (DMBA); karena struktur molekulnya, senyawa karsinogenik benzo(a)pyrene dan DMBA dapat dengan mudah menyisip ke deoxyribonucleic acid (DNA) secara permanen sehingga menyebabkan mutasi genetic (Husain dkk, 2015).

Correspondence:

Vivi Mardina, Biology Department, Faculty of Engineering, Samudra University, Jalan Meurandeh, Langsa Lama, Kota Langsa, Aceh 24354. Email: vmardina@unsam.ac.id 
Berdasarkan laporan World Health Organization (WHO), 75- 80\% dari populasi dunia menggunakan obat herbal untuk mengobati beberapa penyakit kronis termasuk kanker (Safarzadeh et al., 2014). Pengobatan alternatif ini sering menjadi pilihan masyarakat dengan alasan biaya relatif murah, ketersediaan obat yang mudah diperoleh, dan tidak memiliki efek samping yang membahayakan (Arya et al., 2015; Richard et al., 2015). Salah satu tanaman obat yang memiliki potensi sebagai antikanker adalah Sphagneticola trilobata (L.) J.F Pruski (Kour, 2014) (Gambar 1).

Berdasarkan penelitian yang dijalankan sebelumnya (Thomy dan Ginting, 2011), tumbuhan sernai ini menunjukkan aktivitas sitotoksis melalui uji brine shrimp lethality test (BSLT).

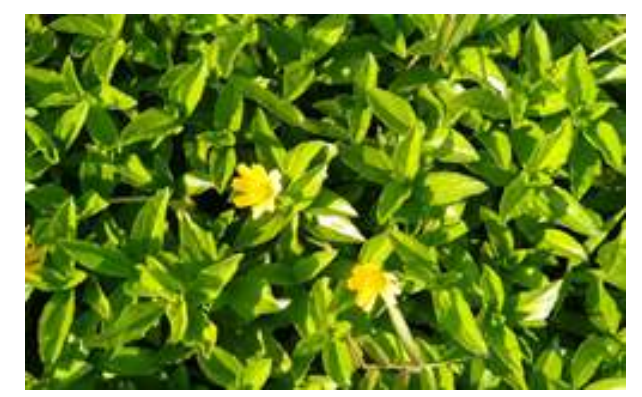

Gambar 1. Deskripsi Sphagneticola trilobata (L.) J.F Pruski

Balekar et al., (2014) mereview Wedelia khususnya spesies Wedelia trilobata dan menyatakan bahwa tanaman Wedelia memiliki aktivitas farmakologik seperti antioksidan, analgesik, anti-inflamasi, anti mikroba, larvasida, tripanosida dan anti tumor. Manjamalai dan Grace (2013) menyatakan bahwa Wedelia chinensis memiliki efek kemopreventif pada kanker paru-paru. Sejauh ini, belum ada data ilmiah penggunaan Sphagneticola trilobata (L.) J.F Pruski sebagai agen anti tumor/ anti kanker secara in vivo, padahal sumber daya alam yang tersedia sangat melimpah di Asia, ditambah lagi kondisi geografis benua Asia sangat mendukung tumbuh sebarnya tanaman sernai S.trilobata (Balekar et al., 2014). Oleh karena itu, penelitian ini bertujuan untuk mengetahui efek anti tumor/kanker ekstrak S.trilobata khususnya pada kasus tumor/kanker payudara yang diinduksi zat karsinogen (DMBA) melalui kajian histologi. Hasil penelitian diharapkan dapat digunakan sebagai data awal pembuktian ilmiah secara invivo mengenai penggunaan S.trilobata sebagai phytomedicine anti kanker terutama pada kanker payudara.

\section{BAHAN DAN CARA KERJA}

Akar dan batang S.trilobata yang dikumpulkan dari daerah Langsa, Aceh pada bulan April 2018 dibersihkan, dikeringkan dan dipotong-potong. Sebanyak $2 \mathrm{~kg}$ bahan dimaserasi dengan larutan n-heksana. Pelarut diganti setiap 24 jam sampai diperoleh larutan jernih. Residu kemudian dimaserasi kembali dengan larutan metanol secara berulang sampai diperoleh larutan jernih. Masing-masing ekstrak dievaporasi sampai diperoleh ekstrak kental untuk kemudian di uji fitokimia (uji Alkaloid, Flavanoid, Saponin, dan steroid) menurut metode yang disarankan Dapas et al. (2014). Hewan uji yang digunakan adalah mencit betina (Mus musculus), berumur 20 hari dengan berat badan \pm 20 g. Hewan coba diadaptasi selama 10 hari, diberi makan secara berlebihan setiap hari (adlibitum), kandang dibersihkan. Hewan yang diuji coba berjumlah 9 ekor dan dibagi menjadi 3 kelompok dengan perlakuan sebagai berikut: 
Kelompok kontrol negatif (K-1) terdiri dari 3 ekor mencit betina yang diberi pakan standard dan diterminasi pada hari ke-30,

Kelompok perlakuan II (K-2) yang terdiri dari 3 ekor mencit betina yang diberi DMBA sebanyak 0.03 $\mathrm{mg} / \mathrm{ekor} /$ hari dan diterminasi pada hari ke-60,

Kelompok perlakuan III (K-3) terdiri dari 3 ekor mencit betina yang diberi DMBA sebanyak $0.03 \mathrm{mg} /$ ekor/hari selama 60 hari dan kemudian diberi ekstrak S.trilobata sebanyak 0.05 $\mathrm{mg} /$ ekor/hari selama 30 hari. Pemberian ekstrak S.trilobata dilakukan secara oral menggunakan alat sonde.

Senyawa karsinogenik DMBA diberikan dalam bentuk larutan dengan melarutkan 100 mg serbuk kristal pada $100 \mathrm{ml}$ minyak zaitun. Larutan DMBA disuntikkan secara subkutan pada daerah payudara kiri bawah mencit. Menurut Pratiwi dkk, (2010), terjadinya kanker pada hewan uji setelah diind uksi DMBA memerlukan waktu sekitar 3,5 minggu. Pembuatan sediaan histologi payudara hewan coba menggunakan metode paraffin: seleksi bahan, fiksasi, pencucian, dehidrasi, penjernihan, infiltrasi paraffin, pemotongan, penempelan, deparaffinasi, pewarnaan serta pemberian label.

\section{Analisis Uji Fungsi Hati dan Ginjal} Uji fungsi hati dengan pengukuran kadar SGPT

Prosedur pengukuran kadar Serum Glutamic Pyruvic Transaminase
(SGPT) mengikuti Meisyayati dkk. (2017) dengan metode UV-test pada panjang gelombang 340nm berdasarkan IFCC. Nilai SGPT dihitung dengan menggunakan rumus :

$$
\text { Aktivitas GPT }\left(\frac{U}{I}\right)=\Delta \text { Abs } / \text { menit } x F
$$

$\mathrm{F}=$ Faktor, 1743, unit aktivitas enzim SGPT perliter darah permenit

\section{Uji Fungsi Ginjal dengan Pengukuran Kreatinin}

Pengukuran kreatinin menggunakan Jaffe method pada panjang gelombang 492 nm (Natsir dkk, 2014). Nilai kreatinin dihitung menggunakan rumus:

Kreatinin (mg/dL)

$=\frac{\Delta \text { Sampel x konsentrasi standar keatinin }}{\Delta \text { Standar }}$

HASIL Identifikasi Senyawa Bioaktif pada
Ekstrak S.trilobata (L.) J.F Pruski

Tabel 1. Hasil identifikasi senyawa bioaktif pada ekstrak metanol dari daun S.trilobata

\begin{tabular}{lc}
\hline $\begin{array}{c}\text { Golongan } \\
\text { senyawa } \\
\text { bioaktif }\end{array}$ & $\begin{array}{c}\text { Ekstrak metanol } \\
\text { daun S.trilobata }\end{array}$ \\
\hline Alkaloid & - \\
Flavonoid & - \\
Saponin & - \\
Steroid & + \\
\hline
\end{tabular}

Keterangan :

$(+)$ : Mengandung senyawa bioaktif

$(-)$ : Tidak mengandung senyawa bioaktif 


\section{Gambaran Histologi Payudara Kelompok Kontrol (K-1)}
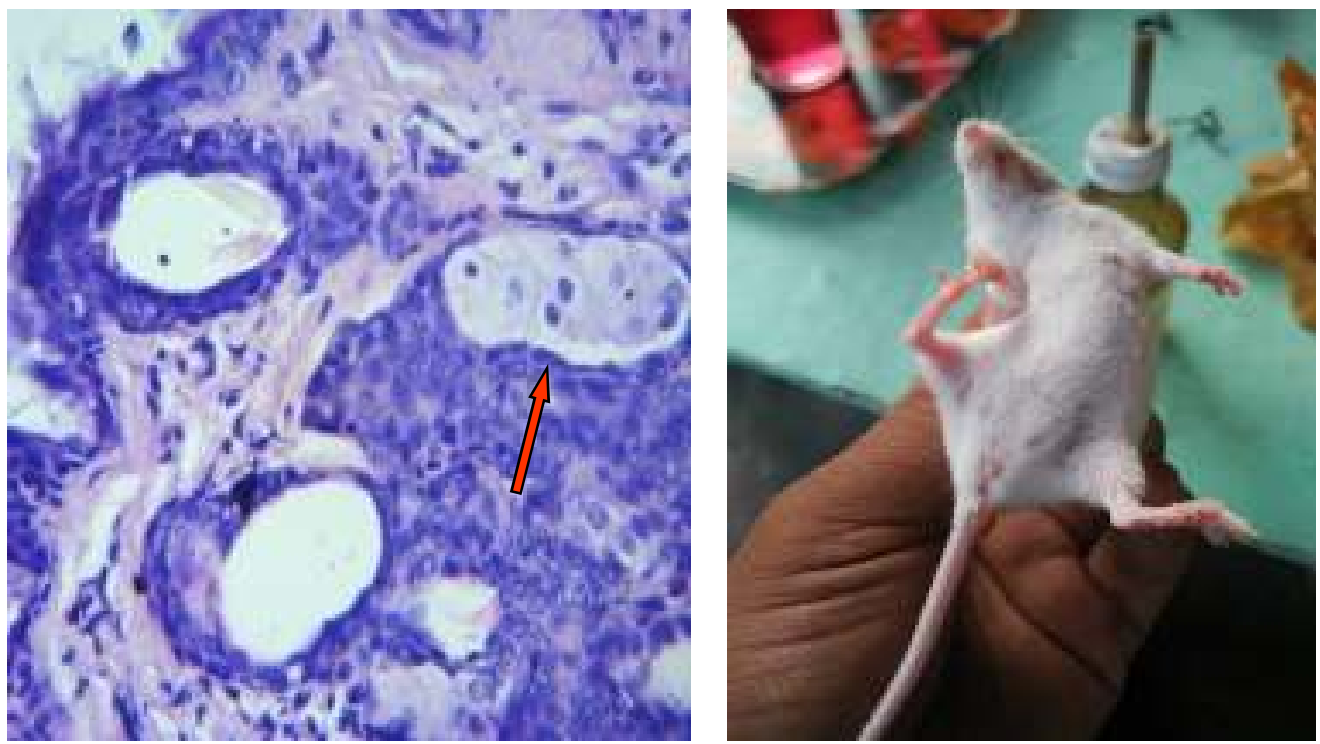

Gambar 2. Gambaran histologi jaringan payudara mencit kelompok kontrol. keterangan: perbesaran 40 kali. tanda panah menunjukkan sel-sel epitel kolumnar duktus laktifer.

\begin{tabular}{llr}
\multicolumn{2}{c}{ Secara mikroskopik } & payudara \\
mencit & kelompok & kontrol \\
memperlihatkan gambaran & histologi \\
jaringan payudara yang normal & norana
\end{tabular}

dengan ciri sel epitel kolumnar yang berada mengelilingi duktus laktiferi (Gambar 2).

\section{Gambaran Histologi Payudara Kelompok Perlakuan II}
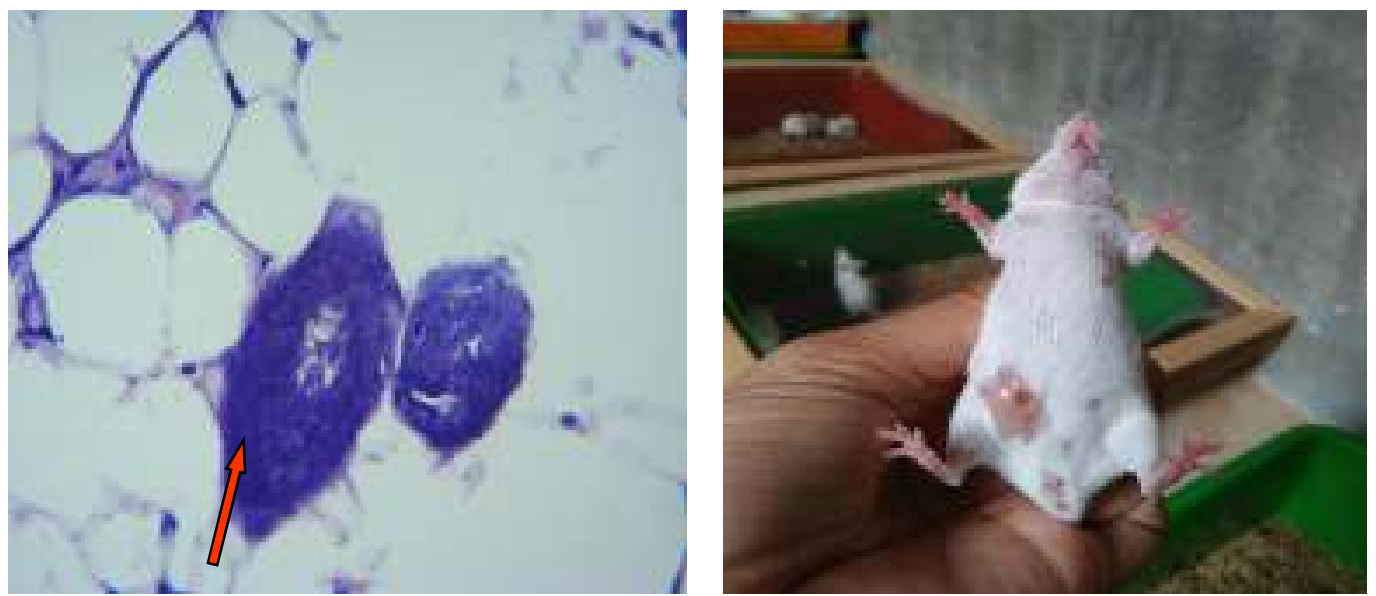

Gambar 3. Gambaran Histologi jaringan payudara mencit kelompok perlakuan II. Keterangan: Perbesaran 40 kali. Tanda panah menunjukkan sel-sel epitel kolumnar duktus laktiferi.

Secara mikroskopik pada lebih dari 4 lapis sel dengan jaringan payudara mencit kelompok perlakuan II menunjukkan terjadinya pertambahan sel-sel epitel kolumnar duktus Laktiferi radang dan kromatin inti kasar yang berwarna ungu gelap (Gambar 3). 


\section{Gambaran Histologi Kelompok Perlakuan III}
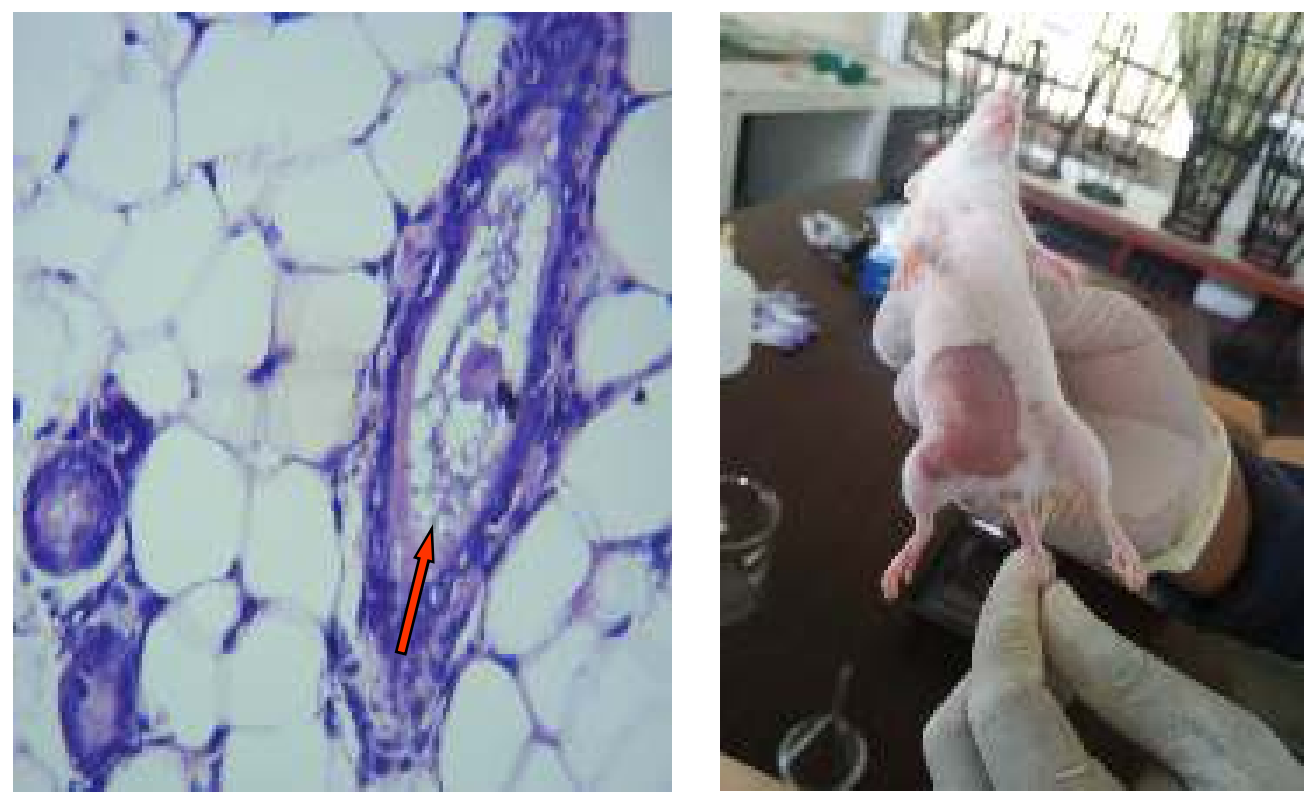

Gambar 4. Gambaran Histologi jaringan payudara mencit kelompok perlakuan III. Keterangan: Perbesaran 40 kali. Tanda panah menunjukkan sel-sel epitel kolumnar duktus laktiferi.

Secara mikroskopik pada sel-sel epitel kolumnar duktus payudara mencit kelompok perlakuan Laktiferi 3 sampai 4 lapis sel (Gambar III menunjukkan adanya pengurangan $4)$.

\section{Analisis KadarALT Dan Kreatinin Mencit (Mus musculus)}

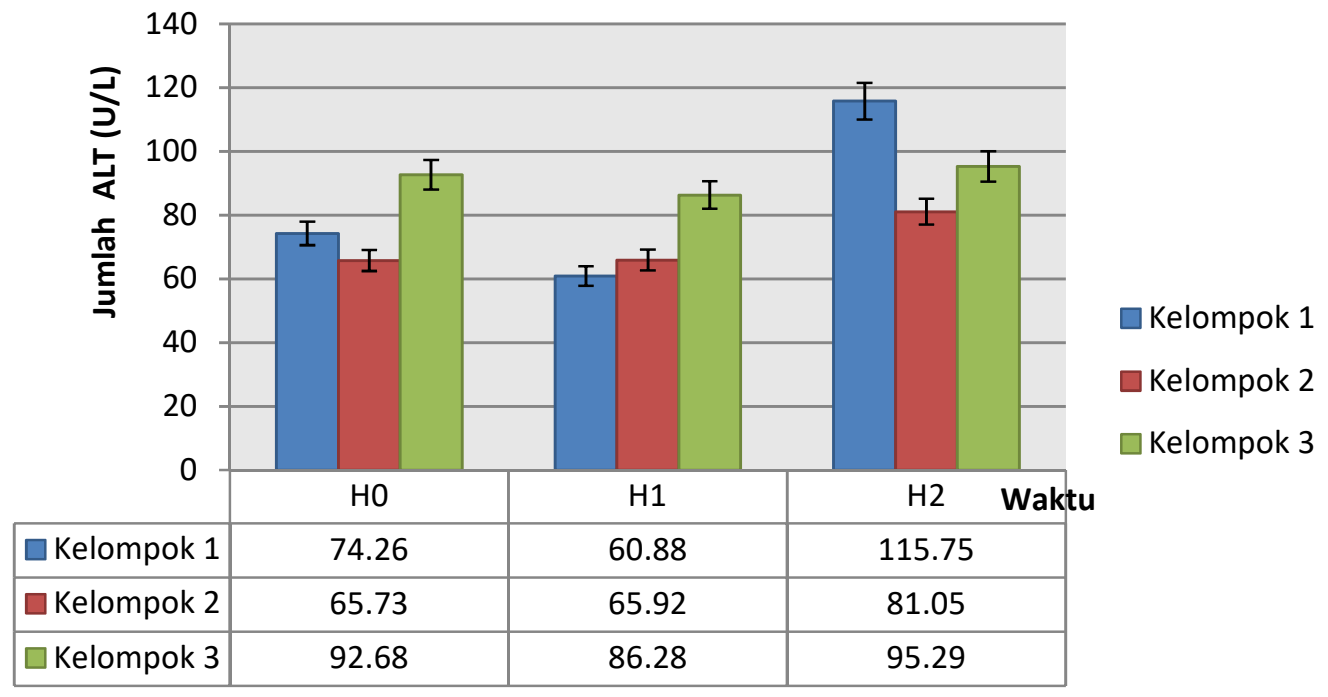

Gambar 5. Kadar ALT 


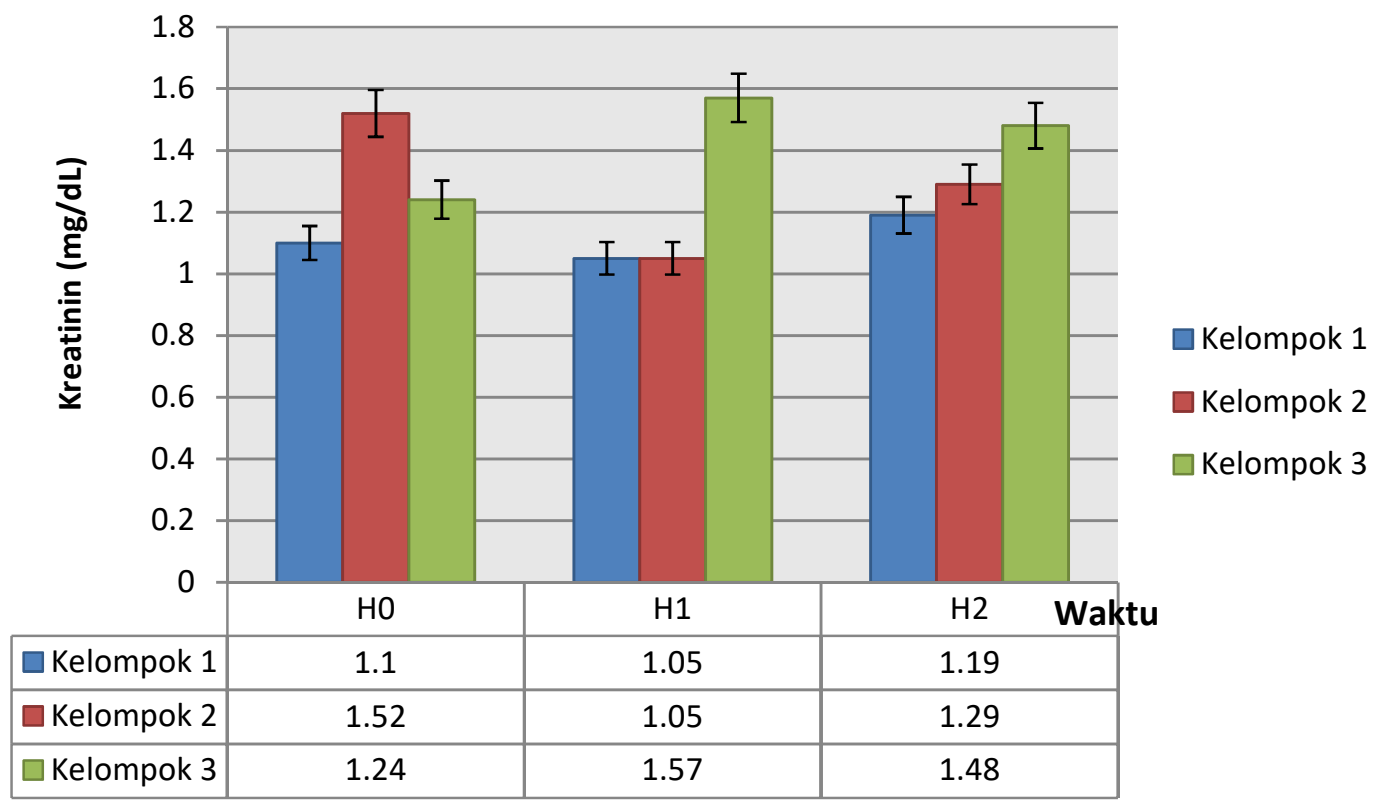

Gambar 6. Kadar Kreatinin

\section{PEMBAHASAN}

DMBA dengan nama ilmiah 7,12 Dimetilbenz(a)antrasena merupakan senyawa polisiklik aromatik hidrokarbon (PAH) yang banyak digunakan sebagai zat penginduksi pertumbuhan kelenjar kanker mamae pada tikus dan mencit. Senyawa ini dipilih karena sifat reaktifnya membentuk adduct DNA yang merupakan reseptor senyawa arylhydrocarbon (AHR) yang sebagian besar terkandung pada kelenjar reproduksi khususnya kelenjar mamae (Pratiwi dkk, 2010; Nansi dkk, 2015). Beberapa penelitian sebelumnya telah menunjukkan tingkat keberhasilan yang tinggi pada pembentukan karsinogen (Pratiwi dkk, 2010; Budi dan Widyarini, 2010).

Penggunaan DMBA ini didasari oleh sifat biologis pada DMBA yang mampu merubah jaringan normal menjadi jaringan kanker melalui mekanisme radikal bebas (Husain dkk, 2015). Radikal bebas dapat diredam oleh aktivias pertahanan metabolit sekunder seperti alkaloid, flavonoid, polifenol, terpenoid, saponin, dan steroid (Yuhernita dan Juniarti, 2011; Lantah et al., 2017). Penelitian ini memilih S.trilobata untuk dikembangkan sebagai pythomedicine agen antitumor/kanker sehingga uji fitokimia diperlukan. Hasil uji fitokimia daun S.trilobata menunjukkan bahwa daun tumbuhan sernai mengandung senyawa steroid. Hal ini sejalan dengan penelitian Thomy dan Ginting (2011). Dapas et al., (2014) melaporkan bahwa metabolit sekunder flavonoid dan steroid berpotensi mencegah dan mengobati kanker dengan aktivitas sitotoksi yang tinggi menggunakan metode Brine Shrimp Lethality Test (BSLT) (nilai LC50 sebesar 3,980 ppm - 9,978 ppm).

Aktivitas sitotoksik yang tinggi dari tanaman S.trilobata (Thomy dan Ginting (2011), perlu pembuktian secara ilmah sehingga penelitian ini memberikan data/gambaran histopatologik payudara, kadar ALT dan kreatinin mencit betina yang diinduksi senyawa karsinogenik DMBA dan kemudian 
ditreatmen dengan ekstrak daun S.trilobata melalui pemberian oral.

Berdasarkan Gambar 3 dan 4, gambaran mikroskopik pada payudara mencit yang diinduksi DMBA 0,05 mg/ekor/hari baik kelompok II, dan III menunjukkan gambaran jaringan payudara yang tidak normal. Hal ini dapat dilihat dari banyaknya jumlah lapisan epitel yang terbentuk. Pada kelompok perlakuan II, jumlah lapisan epitel lebih dari 4 lapis dan pada kelompok perlakuan III setelah diberikan ekstrak daun S.trilobata mengalami pengurangan jumlah lapisan epitel kurang dari 4 lapis.

Senyawa karsinogenik seperti benzo( $\alpha$ )pyrene atau DMBA didalam tubuh mencit akan bereaksi dengan sitokrom P-450 yang berfungsi sebagai katalis oksidator pada lintasan metabolisme steroid, asam lemak, xenobiotik, termasuk obat, racun dan karsinogen membentuk ikatan dengan DNA sel yang aktif sehingga menyebabkan mutasi DNA yang mengakibatkan sel normal menjadi sel neoplastik (Husain dkk, 2015; Pratiwi dkk, 2010). Page et al., 2002 menambahkan bahwa senyawa DMBA sangat bersifat sitotoksik yang dapat menyebabkan apoptosis pada sel murine pra-B. Prasad et al., 2008 menyatakan bahwa DMBA juga dapat mengakibatkan berbagai macam gangguan fungsi organ dan profil darah melalui dua mekanisme kunci yakni memicu pembentukan Reactive Oxigen Species (ROS) dan penurunan antioxidant defense system. Kedua mekanisme tersebut membawa pada kondisi stress oksidatif, yakni ketidak seimbangan antara oksidan dan antioksi didalam tubuh. Dalam kondisi tersebut, tubuh mutlak memerlukan asupan antioksidan dari luar tubuh (eksogen).
SGPT (Serum glutamate piruvat transaminase) yang juga dinamakan ALT (Alanine Aminotransferase), bilirubin, gamma GT (Glutamat transferase), ALP (Alkali Fosfatase), Cholinesterase, merupakan enzim aminotransferase/transaminase yang paling sering dihubungkan dengan kerusakan sel hati. Enzim-enzim ini berfungsi mengkatalisis pemindahan gugus amino secara reversible antara asam amino dan alfa-keto. Apabila terjadi gangguan fungsi hati, enzim aminotransferase di dalam sel akan masuk ke dalam peredaran darah; karena perubahan permeabilitas membran sel, kadar enzim transaminase akan dapat dideteksi dan meningkat dalam peredaran darah. Oleh karena itu pengukuran kadar SGPT/ ALT dapat memberikan informasi yang penting tentang tingkat gangguan fungsi hati karena aktivitas SGPT di dalam hati dapat dideteksi meskipun dalam jumlah yang sangat kecil (Kahar, 2017).

Berdasarkan hasil analisis kadar ALT (Gambar 5). Pada minggu ke-0 perhitungan kadar ALT berkisar antara 71-95 U/L yang dijadikan patokan sebagai nilai normal. Pada hari ke-60 pada perlakuan ke II terjadi peningkatan kadar ALT dari 60,88 U/L menjadi 65,92 U/L, sedangkan kontrol terjadi penurunan dari 74,26 U/L menjadi 65,73 U/L. Setelah hari ke-90 perlakuan ke III yang diinduksi DMBA dan diberi ekstrak S.trilobata mengalami penurunan dari 115,75 U/L menjadi 95,29 U/L.

Tingginya nilai ALT pada perlakuan kelompok II, menunjukan induksi DMBA dapat mengakibatkan terjadinya perubahan fisiologis yaitu terjadi gejala kerusakan fungsi hati. Hal ini dibuktikan dari nilai ALT yang meningkat pada perlakuan II. 
Kreatinin merupakan hasil metabolisme asam organik (kreatin) yang ditemukan dalam jaringan otot. Keberadaan/ konsentrasi kreatinin dapat dideteksi pada urine dan serum dan merupakan salah satu indikator yang penting dalam fungsi ginjal. Oleh karena itu metode pengukuran konsentrasi kreatinin pada penelitian ini menjadi indikasi ilmiah untuk melihat pengaruh zat karsinogen (DMBA) terhadap kerusakan ginjal (Natsir dkk, 2014).

Sama halnya dengan ALT, kreatinin juga diukur pada minggu ke0 ; dimana pada minggu ke-0 ini, mencit belum diberi perlakuan dan diukur kadar kreatinin untuk dijadikan sebagai patokan atau standar nilai normalnya. Berdasarkan Gambar 6 setelah mencit diberi perlakuan dengan DMBA selama 60 hari dan diukur kadar kreatininnya maka hasil menunjukkan bahwa mencit kelompok I yang tidak diberi induksi DMBA mengalami penurunan kadar kreatinin dari $1,1 \mathrm{mg} / \mathrm{dL}$ menjadi 1,05 mg/dL, sedangkan pada kelompok perlakuan III terjadi peningkatan yang drastik yaitu kadar kreatinin yang awalnya 1,24 $\mathrm{mg} / \mathrm{dL}$ menjadi 1,57 mg/dL. Kemudian setelah 60 hari kelompok perlakuan III terpapar zat DMBA, 30 hari berikutnya ditreatmen dengan $S$. trilobata dan hasil menunjukkan bahwa pemberian ekstrak S.trilobatamenurunkan kadar kreatinin $(1,57 \mathrm{mg} / \mathrm{dL}$ menurun menjadi 1,48 $\mathrm{mg} / \mathrm{dL})$.

\section{KESIMPULAN}

Ekstrak methanol daun Wedelia biflora mengandung senyawa bioaktif steroid yang memiliki aktivitas sitotoksik terhadap jaringan payudara mencit (Mus musculus) yang diinduksi senyawa karsinogenik DMBA. Selain pembuktian aktivitas penghambatan prolifersasi sel payudara mencit yang terindusksi DMBA, penurunan kadar ALT dan kreatinin menjadi data pendukung bahwa S.trilobata dapat dijadikan sebagai agen kemopreventif dimasa mendatang.

\section{Ucapan Terima Kasih}

Penulis berterima kasih kepada Kementrian Riset Teknologi DIKTI dan Universitas Samudra atas dukungan finansial melalui DIPA Universitas Samudra dengan no kontrak 427/UN54.6/LT/2018.

\section{KEPUSTAKAAN}

Arya RK, Singh A, Yadav NK, Cheruvu SH, Hossain Z, Meena S, Maheshwari S, Singh AK, Shahab U, Sharma C, Singh K, Narender T, Mitra K, Arya KA, Singh RK, Gayen JR, Datta D 2015. Anti-breast tumor activity of Eclipta extract in-vitro and in-vivo: novel evidence of endoplasmic reticulum specific localization of Hsp60 during apoptosis. Scientific reports. 5 (3): $272-278$.

Balekar N, Nakpheng T, Srichana T 2014. Wedelia trilobata L: a phytochemical and pharmacological review. Chiang Mai Journal Science. Vol. 41 (3): 590 - 605.

Budi RM dan Widyarini S 2010. Dampak Induksi Karsinogenesis Glandula Mammae dengan 7, 12dimetilbenz(a)antrasen terhadap

Dapas CC, Koleangan HSJ, Sangi M 2014. Analisis senyawa metabolit sekunder dan uji toksisitas ekstrak batang bawang laut (Proiphys amboinensis (L.) Herb.) Jurnal MIPA Unsrat, 3 (2): 144148.

Gambaran Histopatologis Lambung Tikus Sprague Dawley. Jurnal Veteriner, Vol. $11(1): 17$ - 23

Husain NP, Kairupan CF, Durry MF 2015. Gambaran histopatologik payudara mencit (Mus musculus) yang diinduksi 
dengan senyawa karsinogenik benzo (a) pyrene dan diberikan ekstrak buah mengkudu (Morinda citrifolia L). Jurnal e-Biomedik, Vol. 3 (1): 1 - 10.

Kahar H 2017. Pengaruh hemolysis terhadap kadar serum glutamate pyruvate transaminase (SGPT) sebagai salah satu parameter fungsi hati. The journal of muhammadiyah medical laboratory technologist. Vol. 2 (1): 38 - 46.

Kour A 2014. Review article: Plants exhibiting potential for cancer treatment. Int. J.Pharm. Sci. Rev.Res. 27 (2): $23-53$.

Lantah PL, Montolalu LADY, Reo AR 2017. Kandungan fitokimia dan aktivitas antioksidan ekstrak methanol rumpul laut. Jurnal Media Teknologi Hasil Perikanan Vol. 5 (3): 167.

Manjamalai A and Grace B 2013. Chemotherapeutic effect of essential oil of Wedelia chinensis (Osbeck) on inducing apoptosis, suppressing angiogenesis and lung metastasis in C57BL/ 6 mice model. Cancer science and therapy journal. 5(7): 271-281.

Meisyayati S, Safitri, Hasanah M 2017. Efek hepatoprotektor fraksi dari ekstrak daun sukun (Artocarpus altilis) terhadap mencit putih jantan galur swiss Webster yang diiduksi parasetamol. Scientia Jurnal farmasi dan kesehatan, 7(2): $129-133$.

Nansi EM, Durry MF, Kairupan C 2015. Gambaran histopatologik payudara mencit (Mus musculus) yang diinduksi benzo(a)pyrene dan diberikan ekstrak kunyit (Curcuma longa L.) jurnal eBiomedik, Vol. 3(1): 510 - 515.

Natsir TA, Siswanta D, Roto 2014. The development of analysis methods of creatinine by spectrophotometry using spectrophotometer UV-visible. Berkala MIPA, 24(1): 12 - 19.

Page TJ, O'Brien S, Jefcoate CR, Czuprynski CJ 2002. 7,12Dimethylbenz[a]anthracene induces apoptosis in murine pre-B cells through a caspase-8-dependent pathway. Mol Pharmacol, 62(2):313-9.
Prasad S, Kalra N, Srivastava S, Shukla Y 2008. Regulation of oxidative stressmediated apoptosis by diallyl sulfide in DMBA-exposed Swiss mice.Hum Exp Toxicol. 27(1):55-63.

Pratiwi D, Hastuti N, Armandari I, Ikawati M, Hermawan A, Meiyanto E 2010. Potensi ekstrak etanolik kulit buah jeruk nipis (Citrus aurantifolia (Cristm.) Swingle) sebagai agen khemopreventif melalui penekanan ekspresi c-Myc dan penghambatan proliferasi pada sel payudara tikus galur Sprague dawley terinduksi 7,12Dimetilbenz(a)antrasena. Majalah obat tradisional, 15 (1): 8 - 15.

Richard TS, Kamdje AHN, Mukhtar F 2015. Medicinal plants in breast cancer therapy. Journal of diseases and medicinal plants, vol. 1(1): 19 - 23.

Rios-Arrabal S, Artacho-Cordon F, Leon J, Roman-Marinetto, Salinas-Asensio M, Calvente I, Nunez MI 2013. Involvement of free radicals in breast cancer, Springerplus, 2: 404.

Safarzadeh E, Shotorbani SS, Baradaran B 2014. Advanced pharmaceutical bulletin, 4 (1): $421-427$.

Shah R, Rosso K, Nathanson SD 2014. Phatogenesis, prevention, and treatment of breast cancer. World journal of clinical oncology., Vol. 5 (3): 283-298.

Thomy Z, Ginting B 2011. Isolation and cytotoxic test of plant secondary metabolites from Sernai (Wedelia biflora L.).Prosiding seminar nasional biologi "Meningkatkan peran biologi dalam mewujudkan national achievement with global reach.USU-Press: 282- 289.

Tiwari P, Bimlesh K, Mandeep K, Gurpreet K, Harleen K 2011. Phytochemical screening and Extraction: A Review. Internationale Pharmaceutica Sciencia, 1 (1): 98-106

Yuhernita dan Juniarti 2011. Analisis senyawa metabolit sekunder dari ekstrak metanol daun surian yang berpotensi sebagai antioksidan. Makara Sains, Vol. 15 (1): 48 - 52. 